\title{
Enfermedad neumocóccica: nuevos retos y propuestas para América Latina
}

\author{
Kattia Camacho-Badilla, Luiza Helena Falleiros-Arlant, José Brea-del Castillo y María L. Ávila-Agüero
}

\section{Resumen}

La enfermedad neumocóccica invasora (ENI) es la primordial causa de muertes prevenibles mediante vacunación en niños bajo 5 años de edad en el mundo; en Latinoamérica y El Caribe representa una enorme carga de enfermedad. Con el fin de combatir la creciente incidencia de ENI en nuestra región, la gran mayoría de los países han incorporado las vacunas neumocóccicas como estrategia preventiva. El grupo GREEN (Grupo Regional de Estudio de la Enfermedad Neumocócica) ha sido creado para estudiar la enfermedad neumocóccica, unificar los datos generados por los países latinoamericanos y detallar la epidemiología pre y post-vacunación neumocóccica.

Palabras clave: Enfermedad neumocóccica invasora, vacunación, vigilancia.

Key words: Invasive pneumococcal disease, vaccination, surveillance.

(Versión en inglés en la página 213)

\section{Introducción}

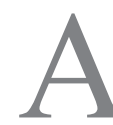
nivel mundial, la enfermedad neumocóccica invasora (ENI) es una infección prevenible por vacunación que cobra alrededor de un millón de vidas cada año ${ }^{1}$. Aproximadamente $90 \%$ de estas muertes ocurren en países en desarrollo. En el 2010, la Organización Mundial de la Salud (OMS) registró 7,6 millones de muertes en niños bajo 5 años de edad, a partir de los cuales aproximadamente 1.000 .000 fueron secundarios a pneumonía ${ }^{2}$. Además, Streptococcus pneumoniae es responsable de una amplia gama de enfermedades tales como faringitis, otitis media aguda, meningitis, artritis séptica, bacteriemia y septicemia ${ }^{3}$.

\section{Antecedentes}

Las enfermedades prevenibles por vacunación son un grupo de entidades que aún en nuestros días representan un reto continuo para la salud pública mundial. Se han convertido en la principal causa de morbilidad y mortalidad en la población general. Los datos publicados por la Organización Panamericana de la Salud (OPS) en el año 2013 indican que la neumonía está dentro de los primeras tres causas principales de morbilidad y mortalidad, y que $S$. pneumoniae sigue siendo el agente más frecuente ${ }^{4}$.

En América Latina y El Caribe, la OMS informa que 1,6 millones de niños bajo 5 años sufren un episodio de ENI y entre 12.000 y 28.000 muertes se producen anualmente ${ }^{5}$. Cada año, los casos de infección neumocóccica se asocian a 182.000 hospitalizaciones (16 por cada 1.000 niños) y 1.412 millones de consultas ambulatorias (121 porcada 1.000 niños), con un costo económico de 333 millones de dólares invertidos en la atención de los pacientes afectados ${ }^{6}$.

Streptococcus pneumoniae sigue teniendo la tasa de mortalidad más alta. De hecho, la mortalidad por meningitis neumocóccica se puede estimar hasta en $60 \%$ en toda la región. Los diferentes serotipos de $S$. pneumoniae muestran diversos patrones de susceptibilidad y muchos son resistentes a los antimicrobianos comúnmente prescritos.

Ante este panorama, expertos de la comunidad científica médica y de salud pública de todo el mundo, han unido sus fuerzas para acelerar la prevención de la enfermedad neumocóccica en niños y adultos. Una de las estrategias de prevención que ha causado mayor impacto en la disminución gradual de la carga de la ENI ha sido la aplicación de vacunas contra este microorganismo.

\section{Estrategias de prevención}

Hoy en día, existe evidencia contundente que en diferentes grupos de edad, las vacunas conjugadas antineumocóccicas (PCVs), no sólo reducen la carga de la enfermedad, sino además la morbilidad, la mortalidad y, por ende, los altos costos de la atención sanitaria de los pacientes afectados, al mismo tiempo que proporciona protección contra la mayoría de los serotipos más comunes ${ }^{7-8}$.

En las regiones de Latinoamérica y El Caribe, las PCVs se han incorporado en la mayoría de los países como parte de los programas de vacunación universal de los niños bajo dos años de edad. También se ha aprobado su uso en pacientes adultos con factores de riesgo subyacentes para $\mathrm{ENI}^{9}$. Recientemente, se ha ampliado la recomendación a los niños y adolescentes de 6 a 17 años con enfermedades crónicas como asma, diabetes mellitus, hemoglobinopatías, neoplasias malignas, enfermedad hepática y los que consumen tabaco ${ }^{10}$.
Servicio de Infectología Pediátrica, Hospital Nacional de Niños, Dr. Carlos Sáenz Herrera. San José, Costa Rica (KC-B, MLA-A). Escuela de Medicina-Pediatría de la Universidad Metropolitana de Santos Sao Paulo, Brasil (LHF-A). Escuela de Medicina-Pediatría del Centro Médico Universidad Central del Este, Santo Domingo, República Dominicana (JBdelC).

Sociedad Latinoamericana de Infectología Pediátrica (SLIPE) (KC-B, LHF-A, JBdelC, MLA-A).

Recibido: 10 de diciembre de 2014

Correspondencia a:

María Luisa Ávila-Agüero avilaguero@gmail.com 


\section{Nuevos retos y propuestas}

Si la enfermedad no reconoce fronteras, la salud tampoco debería reconocerlas. Bajo esta premisa, se creó GREEN (Grupo para el Estudio de la Enfermedad Neumocóccica Regional). Su principal interés es el comportamiento epidemiológico de la enfermedad neumocóccica, su impacto en la población latinoamericana y su control mediante la vacunación. La iniciativa GREEN tiene como objetivo desarrollar un grupo de apoyo para la sociedad civil y las entidades del gobierno, sobre todo en lo que respecta a la enfermedad neumocóccica y su prevención.

Especialistas en enfermedades infecciosas pediátricas, miembros de diferentes sociedades médicas en toda Latinoamérica, colaborarán en la recolección sistemática de datos, el análisis, la investigación y la respectiva publicación. El apoyo adicional también es proporcionado por CIDMA (Center for Infectious Disease Modeling and Analysis) de la Escuela de Salud Pública de la Universidad de Yale, E.U.A.

El objetivo principal de la creación de este grupo es unificar los datos y conocer en detalle la epidemiología, la vacunación pre y post-neumocóccica, de países que son miembros del grupo de estudio GREEN.

Se han propuesto los siguientes objetivos secundarios:

- Crear una red entre los países participantes.

- Recopilar datos epidemiológicos sobre S. pneumoniae en la era pre-vacunación de los países miembros.

- Entender el impacto de las PCVs en la población nacional de los diferentes países miembros a través de la investigación.

- Vigilar el comportamiento de los serotipos en la era posterior a la inmunización.
- Determinar la variabilidad de los serotipos y analizar los grupos de riesgo potenciales, con el fin de detectar a tiempo nuevos serotipos a la luz de la introducción de nuevas vacunas con más serotipos.

Parte del compromiso de los miembros de GREEN es programar reuniones periódicas en diferentes países, con frecuencia semestral o anual para dar a conocer la información recopilada. También tiene como objetivo compartir los resultados de los temas establecidos y mantener la presencia en congresos científicos en toda América Latina y otros países del mundo.

\section{Conclusión}

A pesar de que para el año 2014, 90\% de los niños en América Latina habrá recibido al menos una dosis de PCV, el reto no termina. Los nuevos grupos de riesgo, nuevas vacunas conjugadas con más valencias, el reemplazo de serotipos y la aparición de serotipos no vacunales son puntos clave a tomar en cuenta. La carga de la enfermedad causada por $S$. pneumoniae sigue siendo una preocupación en todo el mundo y por lo tanto en América Latina. Sólo a través del análisis continuo, sistemático y científico podremos controlar las diferentes enfermedades prevenibles por vacunación. Nosotros, como parte de las diferentes sociedades médicas, tenemos la responsabilidad ineludible de contribuir a la salud de nuestra sociedad. Las vacunas brindan salud; no son simples medicamentos y por lo tanto, deben ser reconocidas como un derecho humano. Las vacunas no deben tener fronteras ${ }^{11}$.

\section{Referencias bibliográficas}

1.- O`Brien K L, Wolfson L J, Watt J P, Henkle E, Deloria-Knoll M, et al. Burden of disease caused by Streptococcus pneumoniae in children younger than 5 years: global estimates. Lancet 2009; 374: 893-902.

2.- Liu L, Johnson H L, Cousens S, Perin J, Scott S, Lawn JE, et al. Global, regional and national causes of child mortality: an updated systematic analysis for 2010 with time trends since 2000. Lancet 2012; 379: 2151-61.

3.- Krow Ampofo, Carrie L. Byington. Streptococcus pneumoniae. In: Long S S, Pickering L K, Prober C G, eds. Principles and Practice of Pediatric Infectious Diseases. 4th ed. Philadelphia. Elsevier Inc., 2012: 721-28.

4.- Informe Regional de SIREVA II, 2012. Datos por país y por grupos de edad sobre las características de los aislamientos de Streptococcus pneumoniae, Haemophilus influenzae y Neisseria meningitidis en procesos invasores. In: PAHO, ed. Washington, DC: Pan American Health Organization; 2013: 377.

5.- PAHO. Pneumococcal disease in Latin America kills two children every hour, causes 1.6 million cases of childhood disease every year, new study finds. Available at: http://www.paho.org/ English/DD/PIN/pr061213.htm

6.- Constenla D, Gómez E, de la Hoz F P, O'Loughlin R, Sinha A, Valencia J E, et al. The burden of pneumococcal disease and costeffectiveness of a pneumococcal vaccine in Latin America and the Caribbean. Sabin Vaccine Institute 2007; 1: 129

7.- Black S, Shinefield H R, Ling S, et al. Effectiveness of heptavalent pneumococcal conjugate vaccine in children younger than five years of age for prevention of pneumonia. Pediatr Infect Dis J 2002; 21: 810-15.

8.- Eskola J, Kilpi T, Palmu A, Jokinen J,
Haapakoski J, Herva E, et al. Efficacy of a pneumococcal conjugate vaccine against acute otitis media. N Engl J Med 2001; 344 : 403-9.

9.- CDC. Use of 13-valent pneumococcal conjugate vaccine and 23-valent pneumococcal polysaccharide vaccine among adults $\geq 65$ years: Recommendations of the Advisory Committee on Immunization Practices (ACIP). MMWR 2014; 63 (37): 822-5.

10.- CDC. Use of 13-valent pneumococcal conjugate vaccine and 23-valent pneumococcal polysaccharide vaccine among children age 6-18 years with immunocompromising conditions: Recommendations of the Advisory Committee on Immunization Practices (ACIP). MMWR 2013; 62 (25): 521-4.

11.- Ávila-Agüero M L, Brea-del Castillo J, Falleiros-Arlant L H. Vaccines without borders to Latin America. Expert Rev Vaccines 2013; 12 (11): $1239-40$. 


\title{
Pneumococcal disease: new challenges and new proposals for Latin America
}

\author{
Kattia Camacho-Badilla, Luiza Helena Falleiros-Arlant, José Brea-del Castillo and María L. Ávila-Agüero
}

\section{Summary}

Invasive pneumococcal disease (IPD) is the leading cause of vaccine preventable deaths in children $<5$ years worldwide and it causes a significant disease burden in Latin America and the Caribbean. In order to combat the increasing incidence of IPD in our region, the vast majority of countries have included pneumococcal vaccines as a preventive strategy. The GREEN group (Grupo Regional de Estudio de la Enfermedad Neumocócica) has been created to study pneumococcal disease, unify data from the Latin American countries and learn in detail the epidemiology pre and post-pneumococcal vaccination.

Key words: Invasive pneumococcal disease, vaccination, surveillance.

Palabras clave: Enfermedad neumocóccica invasora, vacunación, vigilancia.

(a Spanish version of this document is found en page 211)

\section{Introduction}

W Orldwide, invasive pneumococcal disease (IPD) is a vaccine preventable disease that charges around a million lives each year ${ }^{1}$. Approximately $90 \%$ of these deaths occur in developing countries. In 2010, the World Health Organization (WHO) recorded 7.6 million deaths in children under 5 years from which approximately 1 million were secondary to pneumonia ${ }^{2}$. In addition, Streptococcus pneumoniae is responsible for a wide range of diseases such as pharyngitis, acute otitis media, meningitis, septic arthritis, bacteremia and septicemia ${ }^{3}$.

\section{Background}

The vaccine-preventable diseases are a group of entities that even in our days represent a continuous challenge to global public health. They have become the main causes of morbidity and mortality in the general population. Data published by the Pan American Health Organization (PAHO) in 2013 indicate that pneumonia is within the first three main causes of morbidity and mortality, and $S$. pneumoniae remains the most frequent agent ${ }^{4}$.

In Latin America and the Caribbean, WHO reports that 1.6 million children under the age of 5 years suffer an episode of IPD each year andamong 12,000 to 28,000 deaths occur anually ${ }^{5}$. Yearly, the cases of pneumococcal infection are associated to 182,000 hospitalizations (16 per 1,000 children) and 1,412,000 ambulatory consultations (121 per 1,000 children), with an economical cost of US\$333 million invested in the care of the affected patients.
Pneumococcus still has the highest fatality rate, estimating that mortality from meningitis in the region can be up to $60 \%$. Different serotypes of pneumococcus show different susceptibility patterns and many are resistant to the antibiotics commonly prescribed.

Faced with this panorama, is that the scientific, medical and public health community experts around the world have joined forces to accelerate the prevention of pneumococcal disease in children and adults. One of the prevention strategies that has caused the most impact on the stepwise decrease in the burden of IPD has been the implementation of vaccines against this organism.

\section{Prevention strategies}

Nowadays, there is robust evidence that pneumococcal conjugate vaccines (PCV) in different age groups, reduce the burden of disease, morbidity, mortality, and hence the high costs in health care attention of the affected patients, providing protection against the most common serotypes $^{7-8}$.

In Latin American and the Caribbean regions, PCV has been incorporated in the majority of countries as part of the universal immunization programs for children under 2 years. It has also been approved for use in adult patients with underlined risk factors for IPD ${ }^{9}$ and has recently expanded the recommendation to children and adolescents aged 6 to 17 years with chronic diseases such as asthma, diabetes, hemoglobinopathies, malignancies, liver disease and those who start with the consumption of tobacco ${ }^{10}$.
Latin American Pediatric Infectious Diseases Society (SLIPE), Pediatric Infectious Diseases Service, National Children's Hospital, Dr. Carlos Saenz Herrera. San José, Costa Rica (KC-B, MLA-A).

Latin American Pediatric Infectious Diseases Society (SLIPE) and Pediatrics-Medical School of the Santos Metropolitan University, Sao Paulo, Brazil (LHF-A).

Latin American Pediatric Infectious Diseases Society (SLIPE) and Pediatrics-Medical School of the Centro Médico Universidad Central del Este, Santo Domingo, República Dominicana (JBdelC).

Sociedad Latinoamericana de Infectología Pediátrica (SLIPE) (KC-B, LHF-A, JBdelC, MLA-A).

Received: 10 de diciembre de 2014

Corresponding author: María Luisa Ávila-Agüero avilaguero@gmail.com 


\section{New challenges, new proposals}

Starting from the premise that if the disease does not recognize borders, health should not recognize it. Joinedby an interest in the epidemiological behavior of pneumococcal disease and its impact on the Latin American population and its control by vaccination, is that GREEN (Group for the Study of Regional Pneumococcal disease) is born. The GREEN initiative aims to develop as a supportive group for the civil society and the state entities, mainly in regards to decision-making about pneumococcal disease and its prevention.

Pediatric Infectious Diseasesspecialists, members of different medical societies throughout Latin America, will collaborate in the systematic data collection, analysis, research and the respective publishing. In addition, we have the support of CIDMA (Center for Infectious Disease Modeling and Analysis) from the School of Public Health at Yale University.

The main purpose of creating this group is to unify data from the member countries of GREEN and then learn in detail the epidemiology pre and post-pneumococcal vaccination.

The following secondary objectives are proposed:

- To create a network between the participating countries.

- To compile epidemiological data about the pneumococcal pre-vaccination era of the member countries.

- To research about the impact of the PCV in the national population of the various member countries.

- To monitor the behavior of the serotypes in the postimmunization era.

- To identify the serotype variability, for subsequent analysis of risk groups and early detection of new serotypes for the introduction of new vaccines with new serotypes.

Part of the commitment of the members of GREEN is to schedule regular meetings in different countries, with a semiannual or annual basis to publicize the collected information. It also aims to maintain a presence at scientific conferences in and outside Latin America and through periodical publications, share the results of the established topics with the rest of the scientific population.

\section{Conclusion}

Although, by 2014 90\% of children in Latin America will receive at least one dose of $\mathrm{PCV}$, the challenge never ends. New risk groups, newervalent conjugate vaccines with more valences, serotype replacement and the emergence of non-vaccine serotypes are key points to consider.

The burden of disease caused by S. pneumoniae remains a concern worldwide and hence in Latin America. Only through ongoing, systematic and scientific analysis is that we can control the different vaccine-preventable diseases. We, as part of the different medical societies, have the ineludible responsibilityto contribute with our society's health. Vaccines bring health, they are not simple drugs andthis is why they should be recognized as a human right. Vaccines should not have borders.

\section{Abstract}

Invasive pneumococcal disease (IPD) is the leading cause of vaccine preventable deaths in children $<5$ years worldwide and it causes a significant disease burden in Latin America and the Caribbean. In order to combat the increasing incidence of IPD in our region, the vast majority of countries have included pneumococcal vaccines as a preventive strategy. The GREEN group (Grupo Regional de Estudio de la Enfermedad Neumocócica) has been created to study pneumococcal disease, unify data from the Latin American countries and learn in detail the epidemiology pre and post-pneumococcal vaccination.

\section{References}

1.- O`Brien K L, Wolfson L J, Watt J P, Henkle E, Deloria-Knoll M, et al. Burden of disease caused by Streptococcus pneumoniae in children younger than 5 years: global estimates. Lancet 2009; 374: 893-902.

2.- Liu L, Johnson H L, Cousens S, Perin J, Scott S, Lawn JE, et al. Global, regional and national causes of child mortality: an updated systematic analysis for 2010 with time trends since 2000. Lancet 2012; 379: 2151-61.

3.- Krow Ampofo, Carrie L. Byington. Streptococcus pneumoniae. In: Long S S,
Pickering L K, Prober C G, eds. Principles and Practice of Pediatric Infectious Diseases. 4th ed. Philadelphia. Elsevier Inc., 2012: 721-8.

4.- Informe Regional de SIREVA II, 2012. Datos por país y por grupos de edad sobre las características de los aislamientos de Streptococcus pneumoniae, Haemophilus influenzae y Neisseria meningitidis en procesos invasores. In: PAHO, ed. Washington, DC: Pan American Health Organization; 2013: 377.

5.- PAHO. Pneumococcal disease in Latin America kills two children every hour, causes 1.6 million cases of childhood disease every year, new study finds. Available at: http://www.paho.org/ English/DD/PIN/pr061213.htm

6.- Constenla D, Gómez E, de la Hoz F P, O’Loughlin R, Sinha A, Valencia J E, et al. The burden of pneumococcal disease and costeffectiveness of a pneumococcal vaccine in Latin America and the Caribbean. Sabin Vaccine Institute 2007; 1: 129

7.- Black S, Shinefield H R, Ling S, et al. Effectiveness of heptavalent pneumococcal conjugate vaccine in children younger than five years of age for prevention of pneumonia. Pediatr Infect Dis J 2002; 21: 810-15.

8.- Eskola J, Kilpi T, Palmu A, Jokinen J, 
Haapakoski J, Herva E, et al. Efficacy of a pneumococcal conjugate vaccine against acute otitis media. N Engl J Med 2001; 344 . 403-9.

9.- CDC. Use of 13-valent pneumococcal conjugate vaccine and 23-valent pneumococcal polysaccharide vaccine among adults $\geq 65$ years: Recommendations of the Advisory Committee on Immunization Practices (ACIP). MMWR 2014; 63 (37): 822-5.

10.- CDC. Use of 13-valent pneumococcal conjugate vaccine and 23-valent pneumococcal polysaccharide vaccine among children age 6-18 years with immunocompromising conditions:
Recommendations of the Advisory Committee on Immunization Practices (ACIP). MMWR 2013; 62 (25): 521-4.

11.- Ávila-Agüero M L, Brea-del Castillo J, Falleiros-Arlant L H. Vaccines without borders to Latin America. Expert Rev Vaccines 2013; 12 (11): 1239-40 